\title{
Captopril Inhibits Angiogenesis and Slows the Growth of Experimental Tumors in Rats
}

\author{
Olga V. Volpert, ${ }^{\star}$ William F. Ward, ${ }^{\ddagger}$ Mark W. Lingen, ${ }^{\S}$ Louis Chesler, ${ }^{\S}$ Dennis B. Solt, ${ }^{\S}$ Mark D. Johnson, ${ }^{\S}$ Agostino Molteni, ${ }^{\S}$ \\ Peter J. Polverini, $\|$ and Noël P. Bouck* \\ Departments of *Microbiology-Immunology, ${ }^{\ddagger}$ Radiology, and ${ }^{\S}$ Pathology, and R. H. Lurie Cancer Center, Northwestern University \\ Medical School, Chicago, Illinois 60611; and ${ }^{\|}$University of Michigan School of Dentistry, Department of Oral Medicine, Pathology \\ and Surgery, Ann Arbor, Michigan 48109
}

\begin{abstract}
Captopril, an inhibitor of angiotensin converting enzyme, is widely used clinically to manage hypertension and congestive heart failure. Here captopril is shown to be an inhibitor of angiogenesis able to block neovascularization induced in the rat cornea. Captopril acted directly and specifically on capillary endothelial cells, inhibiting their chemotaxis with a biphasic dose-response curve showing an initial decrease at clinically achievable doses under $10 \mu \mathrm{M}$ and a further slow decline in the millimolar range. Captopril inhibition of endothelial cell migration was not mediated by angiotensin converting enzyme inhibition, but was suppressed by zinc. Direct inhibition by captopril of zinc-dependent endothelial cell-derived 72- and 92-kD metalloproteinases known to be essential for angiogenesis was also seen. When used systemically on rats captopril inhibited corneal neovascularization and showed the antitumor activity expected of an inhibitor of angiogenesis, decreasing the number of mitoses present in carcinogen-induced foci of preneoplastic liver cells and slowing the growth rate of an experimental fibrosarcoma whose cells were resistant to captopril in vitro. These data define this widely used drug as a new inhibitor of neovascularization and raise the possibility that patients on long term captopril therapy may derive unexpected benefits from its antiangiogenic activities. (J. Clin. Invest. 1996. 98: 671-679.) Key words: neovascularization • gelatinases • endothelial cells $\bullet$ chemotaxis $\bullet$ captopril
\end{abstract}

\section{Introduction}

Captopril (D-3-mercapto-2-methylpropanoyl-L-proline) is an orally active competitive inhibitor of angiotensin-converting enzyme (ACE), ${ }^{1}$ a $\mathrm{Zn}^{2+}$-dependent carboxypeptidase that

Address correspondence to Noël Bouck, R. H. Lurie Cancer Center, Northwestern University Medical School, 303 East Chicago Avenue, Chicago, IL 60611. Phone: 312-503-5934; FAX: 312-908-1372; E-mail: n-bouck@ nwu.edu. Mark D. Johnson's current address is USEPA, 77 W. Jackson Blvd., Chicago, IL 60604.

Received for publication 15 December 1995 and accepted in revised form 6 May 1996.

1. Abbreviations used in this paper: ACE, angiotensin-converting enzyme; bFGF, basic fibroblast growth factor.

J. Clin. Invest.

(C) The American Society for Clinical Investigation, Inc.

0021-9738/96/08/0671/09 \$2.00

Volume 98, Number 3, August 1996, 671-679 converts angiotensin I to the potent vasoconstrictor angiotensin II and inactivates the bradykinins $(1,2)$. Due to its free thiol group, captopril is also an effective radical scavenger and antioxidant. The drug is taken by $5-10$ million people worldwide in the management of hypertension and heart failure (2-5).

In addition to its ability to reduce blood pressure, captopril has a number of other biological activities (2). It can ameliorate arthritis (6), reverse diabetic retinopathy (7), enhance insulin sensitivity (2), lower thrombotic risk $(8,9)$, decrease atherosclerosis and renal failure (10-12), and lower the incidence of radiation-induced pulmonary damage and radiation-induced fibrosarcomas in rats $(13,14)$. This broad range of effects suggests that captopril has multiple activities in vivo, only a portion of which can be attributed to its hypotensive action.

Several of the diseases that respond favorably to captopril, including arthritis, diabetic retinopathy, atherosclerosis and cancer are angiogenesis dependent (15), raising the possibility that captopril could be limiting their progression in part by inhibiting the new blood vessel growth on which their pathology depends. Captopril can also have a negative effect on the stability of vessels, for long term systemic treatment increases arteriolar rarefaction in both normotensive and hypertensive animals (16). In addition, angiotensin II, the product of the enzymatic reaction that captopril inhibits, induces neovascularization in experimental systems (17-19) and enhances vessel density in muscle tissue (20).

Here we demonstrate that captopril itself inhibits neovascularization in vivo and interacts directly with cultured endothelial cells in vitro to block their chemotaxis toward an inducer of angiogenesis. The inhibition of the migration of endothelial cells was not dependent on ACE inhibition, but may be the result of the ability of captopril to inhibit the activity of the $\mathrm{Zn}^{2+}$ dependent metalloproteinases that endothelial cells require to respond to an angiogenic stimulus. To determine if systemic captopril could inhibit an angiogenesis-dependent disease, two rat tumor models were used. Captopril was effective in both, decreasing mitoses in foci of diethylnitrosamine-induced preneoplastic liver foci and slowing the growth of syngeneic fibrosarcomas growing subcutaneously.

\section{Methods}

Drugs. Captopril was generously provided by Bristol Meyers/Squibb (Princeton, NJ) and lisinopril by Merck Research Laboratory (West Point, PA). Penicillamine and angiotensin II were purchased from Sigma Chemical Co. (St. Louis, MO). Enalaprilat, the active derivative of enalapril, was a gift from Dr. Daniel Battle, Northwestern University Medical School (Chicago, IL). Angiotensin II receptor 1 ( $\mathrm{AT}_{1}$ ) antagonist L-158,809,000M (Merck Research Laboratory) was provided by Dr. John Moulder, Medical College of Wisconsin (Milwaukee, WI). The $\mathrm{AT}_{2}$ receptor antagonist PD123,319 ditrifluoroacetate came from Research Biochemicals, Inc., (Natick, MA). 
Endothelial cell migration assay. Bovine adrenal capillary endothelial cells (kindly provided by Dr. J. Folkman, Children's Hospital, Boston, MA) were grown in DME containing $10 \%$ donor calf serum (Flow Laboratories, McLean, VA) and $100 \mu \mathrm{g} / \mathrm{ml}$ endothelial cell mitogen (Biomedical Technologies, Stoughton, MA) and used between passage 13 and 15 . To measure migration, cells were starved overnight in DME containing $0.1 \%$ BSA. The cells were then harvested, suspended in DME with $0.1 \%$ BSA, and plated at $1.75 \times 10^{4}$ per well on the lower surface of a gelatinized 5.0- $\mu \mathrm{M}$ filter (Nucleopore Corp., Pleasanton, CA) in an inverted modified Boyden chamber as described previously (21). After $1-2 \mathrm{~h}$ at $37^{\circ} \mathrm{C}$, during which time the cells adhere to the filter, the chamber was reinverted, test solutions were added to the top well, and the chamber was incubated for 3-4 h at $37^{\circ} \mathrm{C}$. The chambers were then disassembled, the filters fixed and stained, and the number of cells that had migrated to the top of the filter in 10 high power fields counted. DME containing $0.1 \%$ BSA was used as a negative control, and $10 \mathrm{ng} / \mathrm{ml}$ of basic fibroblast growth factor (bFGF) as a positive control. Where indicated $\mathrm{ZnCl}_{2}$ or other test substances were added to top wells. Each sample was tested in quadruplicate in a single experiment, and each experiment was repeated at least twice. To test for toxicity, endothelial cells treated in parallel with those in the Boyden chamber assay were evaluated for trypan blue exclusion

Neovascularization of the rat cornea. Female Fischer 344 rats (Harlan Industries, Indianapolis, IN) weighing 120-140 grams were housed in the Northwestern University Center for Experimental Animal Resources in accord with National Institutes of Health guidelines and operated upon using a research protocol approved by the Institutional Animal Care and Use Committee. Hydron (Interferon Sciences, New Brunswick, NJ) pellets of $<5 \mu$ l were formulated containing, where indicated, captopril at a variety of concentrations and/ or bFGF at $0.15 \mu \mathrm{M}$. Pellets were implanted into the corneas of anesthetized rats (sodium pentobarbital, $30 \mathrm{mg} / \mathrm{kg}$, i.p.) $1.0-1.5 \mathrm{~mm}$ from the limbus as described previously (22). Neovascularization was as-

Table I. The Effect of Captopril on Neovascularization Induced by bFGF in the Rat Cornea

\begin{tabular}{|c|c|c|c|}
\hline $\begin{array}{c}\mathrm{bFGF} \\
(0.15 \mu M)\end{array}$ & $\begin{array}{l}\text { Captopril } \\
(m M)\end{array}$ & $\begin{array}{c}\text { Positive } \\
\text { corneas/ } \\
\text { total implanted }\end{array}$ & $\begin{array}{l}\text { Percent } \\
\text { positive }\end{array}$ \\
\hline & $\begin{array}{l}\text { Drug } \\
\text { implanted } \\
\text { in cornea }\end{array}$ & & \\
\hline - & 0.0 & $0 / 7$ & 0 \\
\hline- & 0.05 & $0 / 4$ & 0 \\
\hline- & 5.0 & $0 / 4$ & 0 \\
\hline- & 50 & $0 / 6$ & 0 \\
\hline+ & 0.0 & 9/9 & 100 \\
\hline+ & 0.05 & $4 / 4$ & 100 \\
\hline+ & 5.0 & $2 * / 4$ & 50 \\
\hline+ & 50 & $0 / 7$ & 0 \\
\hline+ & 200 & $0 / 4$ & 0 \\
\hline+ & $\begin{array}{l}\text { Systemic } \\
\text { treatment } \\
\text { with drug }\end{array}$ & $2 * / 6$ & 33 \\
\hline
\end{tabular}

Where indicated captopril and/or bFGF were incorporated into noninflammatory pellets which were implanted into the rat cornea. Ingrowth of vessels from the limbus into the normal avascular cornea was assessed after $7 \mathrm{~d}$. *Generalized suppression of neovascularization was noted, but inhibition was only partial in two corneas. ${ }^{\ddagger}$ Rats received captopril in their drinking water from $4 \mathrm{~d}$ before implant until death. Pellets contained only bFGF. sessed 3, 5, and $7 \mathrm{~d}$ later. Vigorous sustained ingrowth of vessels from the limbus to the pellet by day 7 was considered a positive response. To provide a permanent record of the response, animals were anesthetized, then perfused via the abdominal aorta with colloidal carbon to label vessels. Eyes then were fixed in formalin, and corneas excised, flattened and photographed. In one experiment animals received drinking water containing $0.4 \mathrm{mg} / \mathrm{ml}$ captopril from $11 \mathrm{~d}$ before implant until death. All animals continued to gain weight and appear healthy during treatment.

Metalloproteinase assays. Enzymes secreted by capillary endothelial cells were obtained by collecting serum-free conditioned media from bovine capillary endothelial cells as previously described (22), and were tested for metalloproteinase activity by zymography (23). Fifteen microliters of threefold-concentrated conditioned medium was suspended in nonreducing Laemmli SDS-PAGE sample buffer without $\beta$-mercaptoethanol. Samples were loaded without prior boiling onto a $4 \%$ gel that contained $0.1 \%$ gelatin, and run at $125 \mathrm{~V}$ for
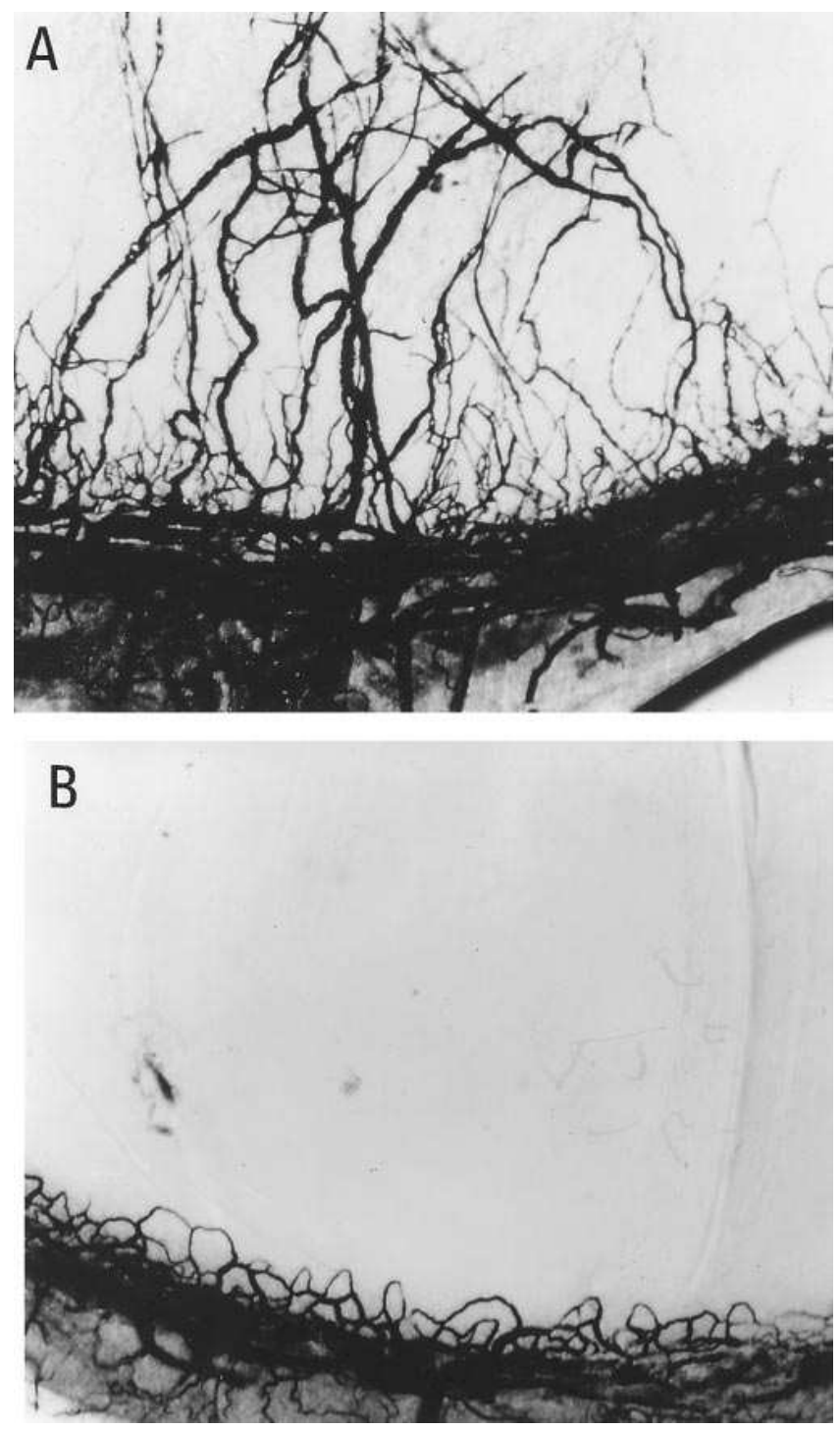

Figure 1. Inhibition of corneal neovascularization by captopril. (A) Hydron pellet was implanted into the rat cornea $1.5 \mathrm{~mm}$ from the limbus and $7 \mathrm{~d}$ later vessels visualized with colloidal carbon. Pellet containing $0.15 \mu \mathrm{M}$ bFGF. Note vigorous new vessels growing from limbus toward pellet. (B) Pellet containing $0.15 \mu \mathrm{M}$ bFGF plus $50 \mathrm{mM}$ captopril. Note absence of neovascularization. 
$1.5 \mathrm{~h}$ at $4^{\circ} \mathrm{C}$. After electrophoresis, gels were incubated twice for 30 $\min$ in $2.5 \%$ Triton X-100 to remove SDS and permit enzyme renaturation. Gels were then cut into single lane strips and incubated overnight in substrate buffer $(50 \mathrm{mM}$ Tris- $\mathrm{HCl}, \mathrm{pH} 7.6,150 \mathrm{mM}$ $\mathrm{NaCl}, 10 \mathrm{mM} \mathrm{CaCl}, 0.05 \%$ [wt/vol] Brij-35, and $0.02 \%$ sodium azide), in the presence of various concentrations of captopril. Gels were stained with $0.5 \%$ Coomassie blue, destained, and bands quantitated by densitometry.

To test the effect of captopril on purified enzyme, a radio-labeled gelatin substrate cleavage assay was used (24) with purified $72 \mathrm{kD}$ gelatinase (a generous gift from W. Stetler-Stevenson, National Cancer Institute, Bethesda, MD). From preliminary experiments, an enzyme concentration of $5 \mathrm{ng} / \mathrm{ml}$ was chosen as being on the linear portion of the dose-response curve and giving $75 \%$ maximal activity. For this substrate, the enzyme was incubated for $4 \mathrm{~h}$ at $37^{\circ} \mathrm{C}$ in reactions containing $2 \times 10^{6} \mathrm{cpm}\left[{ }^{14} \mathrm{C}\right]$ gelatin substrate plus various concentrations of captopril. The reactions were then diluted into $10 \%$ trichloroacetic acid, the uncleaved substrate pelleted at $10,000 \mathrm{~g}$ for $10 \mathrm{~min}$ at $4^{\circ} \mathrm{C}$, and aliquots of the supernatant counted. The enzyme activity was expressed as the TCA soluble cpm released per mg protein.

Chemical induction of tumors. The Solt-Farber model was used to induce foci of preneoplastic liver cells in rats (25). Tumors were
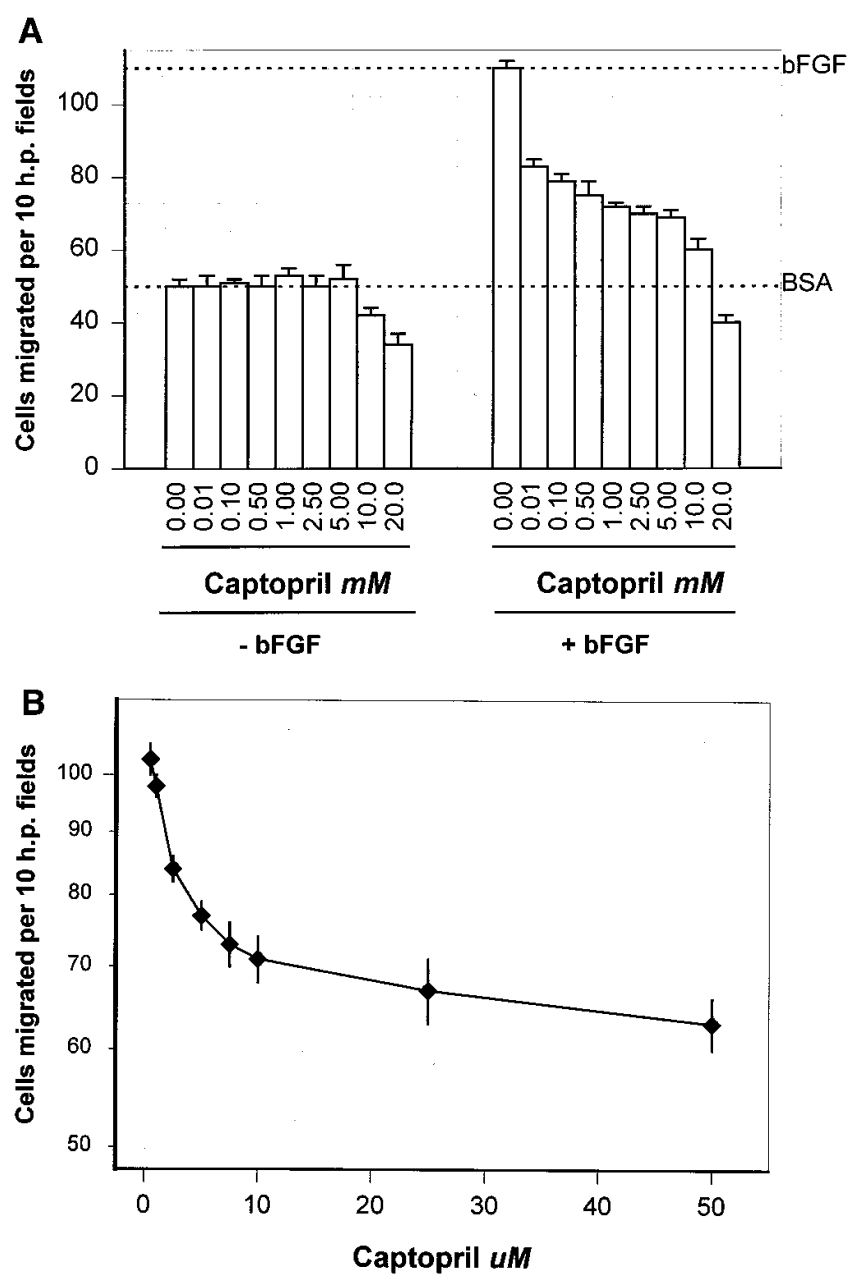

Figure 2. Inhibition of capillary endothelial cell migration by increasing concentrations of captopril. $(A)$ The effect of captopril concentrations in the millimolar range on the migration of capillary endothelial cells in a modified Boyden chamber in the presence (+bFGF) or absence $(-\mathrm{bFGF})$ of a gradient of bFGF. Error bars indicate SEM. $(B)$ Expansion of the dose-response curve in the presence of bFGF at low micromolar concentrations of captopril. initiated on day 1 in Fischer-344 rats with 50, 100, or $150 \mathrm{mg}$ of diethylnitrosamine (DEN) per kilogram body weight intraperitoneally and on day 14 animals were put on chow containing $0.02 \%$ acetylaminofluorine. On day 21 animals were subjected to a $2 / 3$ partial hepatectomy, and killed on day 30. Control rats received water ad libitum, and experimental animals received water containing captopril at 0.4 $\mathrm{mg} / \mathrm{ml}$ which results in a dose of $\sim 50 \mathrm{mg} / \mathrm{kg}$ per $\mathrm{d}$ from $3 \mathrm{~d}$ before carcinogen injection until autopsy. Upon death, liver tissue was fixed in formalin, sectioned at $6 \mu \mathrm{m}$, and stained with hematoxylin and eosin. The surface area of basophilic foci representing clones of preneoplastic cells was measured using a micrometer grid at a magnification of 100 , and the mitoses within these foci counted.

Implanted tumors. Fisher strain F344 female rats were injected subcutaneously with $5 \times 10^{6}$ syngeneic methylcholanthrene-induced sarcoma cells (26) in the right and left flanks and were examined daily through day 29. The cross sectional area of each tumor was determined by measuring the tumor in two dimensions using a caliper. Three to four rats were used per group. Captopril-fed rats were dosed as described above with drug in their drinking water throughout the experiment.

Statistical analysis. The significance of differences between group means was determined by the Student's $t$ test.

\section{Results}

Inhibition of in vivo neovascularization by captopril. Captopril was incorporated into noninflammatory Hydron pellets and the pellets were tested for ability to induce neovascularization by implanting them in the normally avascular rat cornea $\mathrm{Ta}$ ble I). Captopril by itself was unable to stimulate angiogenesis
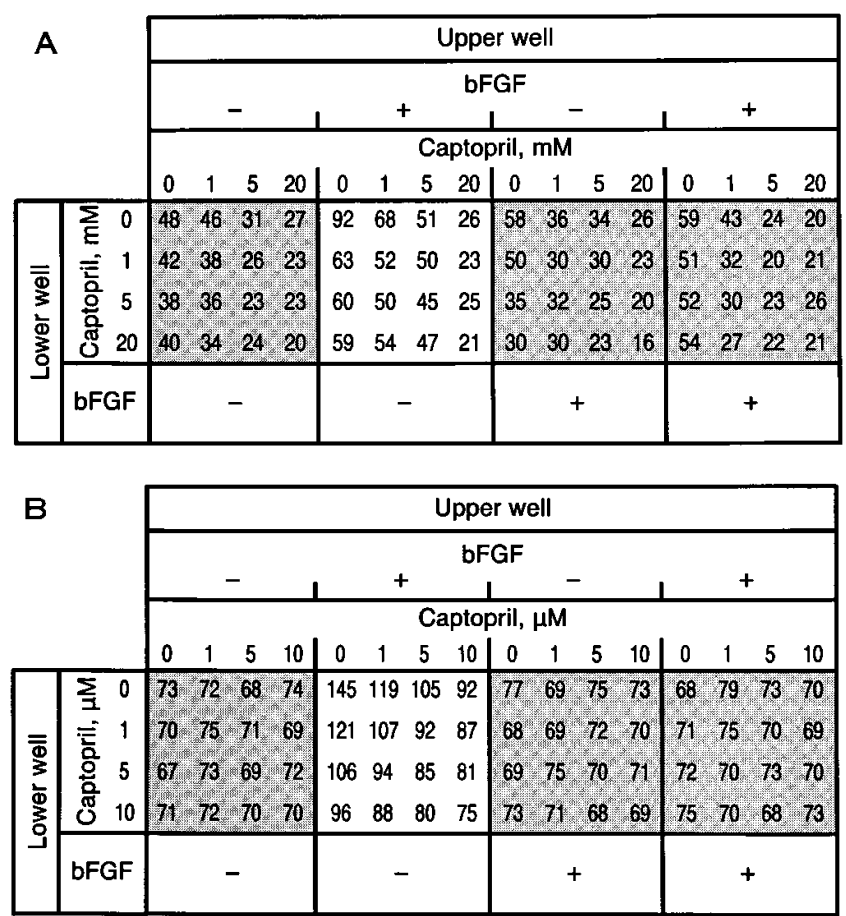

Figure 3. Captopril inhibition of both directional chemotaxis and random chemokinesis. A checkerboard analysis of the migration of capillary endothelial cells from the lower to the upper well of a Boyden chamber in the presence and absence of a positive gradient of bFGF. (A) Millimolar concentrations of captopril. (B) Micromolar concentrations of captopril. Clear box highlights the wells where cells were migrating up a positive gradient towards bFGF. 

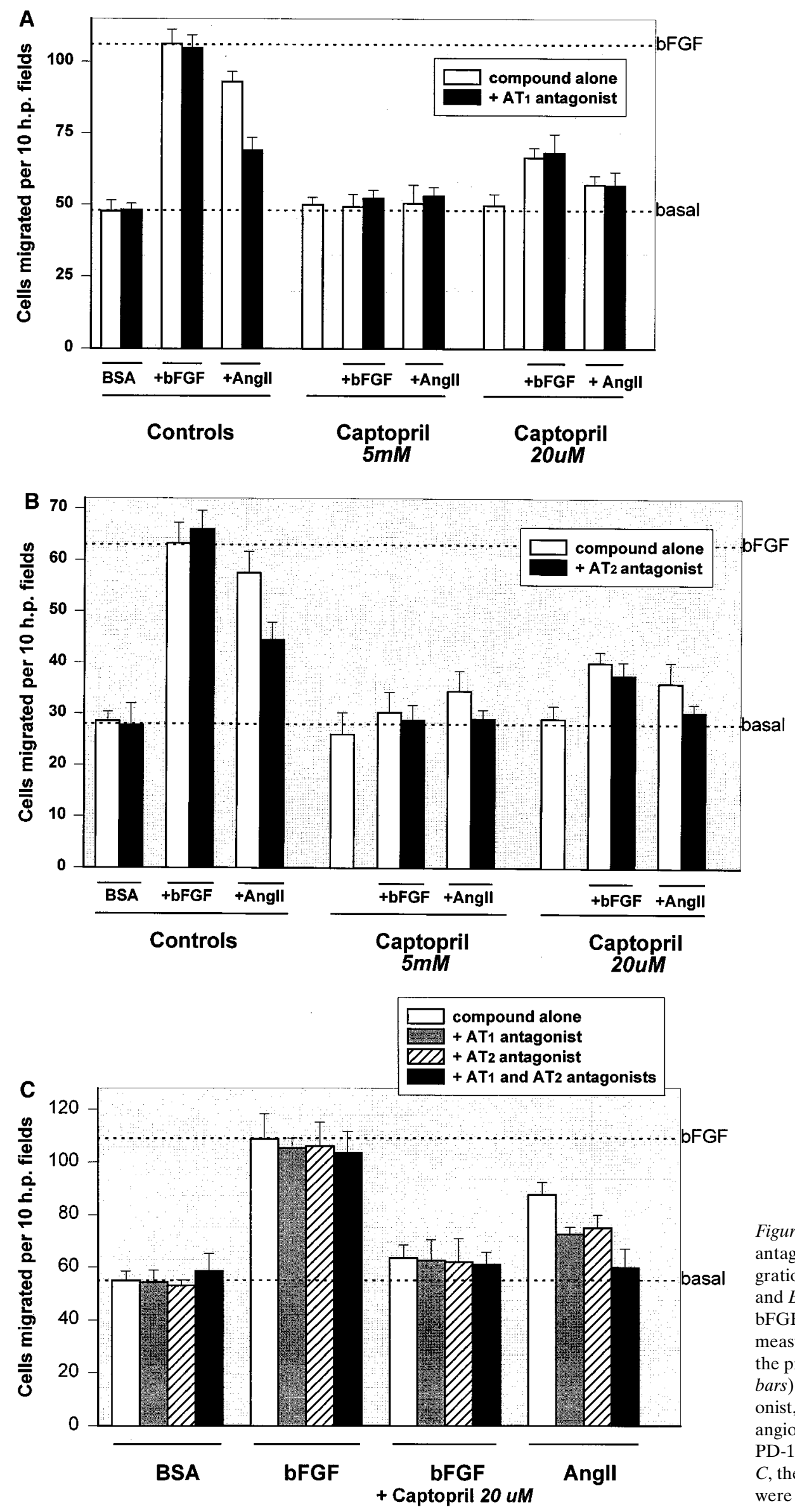

Figure 4. Inability of angiotensin II receptor antagonists to influence endothelial cell migration or prevent captopril inhibition. In $A$ and $B$, endothelial cell migration toward bFGF or toward angiotensin II at $1 \mu \mathrm{g} / \mathrm{ml}$ was measured at high and low doses of captopril in the presence (clear bars) or absence (dark bars) of the angiotensin II $\mathrm{AT}_{1}$ receptor antagonist, $\mathrm{L}-158,809-000 \mathrm{M}$, at $1 \mu \mathrm{M}(A)$ or the angiotensin $\mathrm{II}_{2}$ receptor antagonist, PD-123,319 ditrifluoroacetate at $1 \mu \mathrm{M}(B)$. In $C$, these angiotensin II receptor antagonists were combined (dark bar). SEM is indicated. 

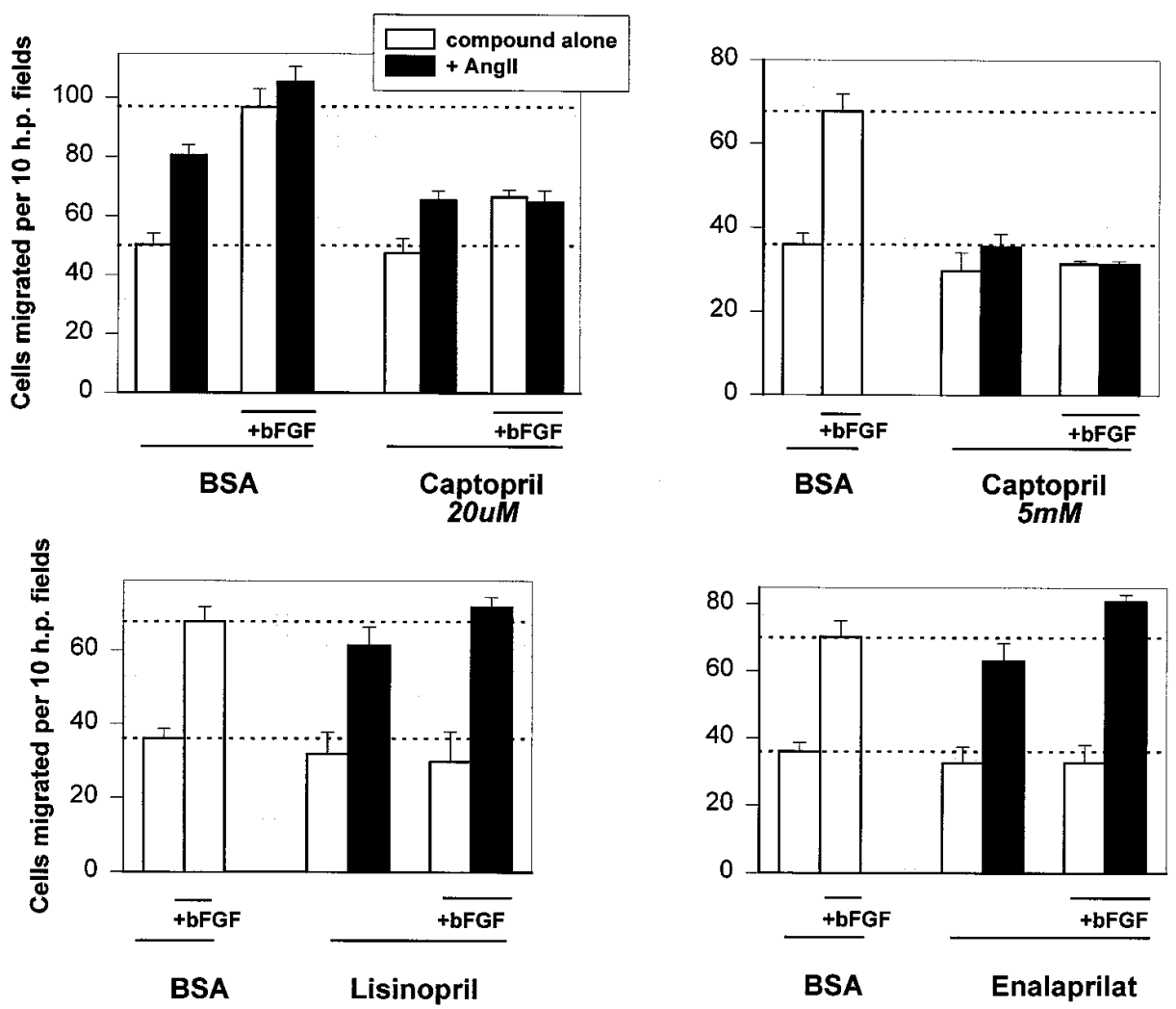

Figure 5. Ability of captopril but not other ACE inhibitors to inhibit endothelial cell migration induced by angiotensin II. The effect of high and low concentrations of captopril on endothelial cell migration in the presence and absence of bFGF and angiotensin II (1 ( $\mu / \mathrm{ml}$; dark bars) was compared to that of other active ACE inhibitors lisinopril and enalaprilat.

when tested over a wide dose range. However, when the angiogenic stimulus bFGF was incorporated into pellets along with captopril, the drug inhibited bFGF-induced corneal neovascularization (Table I and Fig. 1). An increase in inhibitory activity could be seen with an increase in captopril concentration. Systemic treatment with captopril in drinking water from $4 \mathrm{~d}$ before implanting pellets to $7 \mathrm{~d}$ after also rendered the animals unable to mount a vigorous corneal response towards bFGF (Table I).

Inhibition of in vitro endothelial cell migration by captopril. To determine if captopril was acting directly on endothelial cells rather than on accessory cells such as mast cells and macrophages that can be responsible for the development of an angiogenic response in vivo, the effect of the drug on the migration of cultured capillary endothelial cells was measured. The inhibition of the migration of capillary endothelial cells toward a positive angiogenic stimulus has correlated well with the ability of a variety of agents to block neovascularization in vivo $(27,28)$. Cells were plated on the bottom of a gelatinized filter in a modified Boyden chamber and their migration toward bFGF in the top well measured. In this assay captopril was able to inhibit bFGF-induced migration at concentrations ranging from $1 \mu \mathrm{M}$ to $10 \mathrm{mM}$ (Fig. 2). The dose-response curve was biphasic, with a sharp drop in migration seen at captopril concentrations $<10 \mu \mathrm{M}$, followed by a slower decline in inhibitory activity as the concentration of captopril rose into the millimolar range (Fig. $2 \mathrm{~B}$ ). Control migrations using proline, the parent compound for captopril, at 1 and $5 \mathrm{mM}$ showed no inhibition (data not shown). In the absence of stimulatory bFGF, captopril had no effect on basal migration up to concentrations of 5-10 mM (Fig. $2 \mathrm{~A}$, left) indicating that it was not toxic to the endothelial cells. In addition, viability, as measured by trypan blue exclusion, did not fall when cells were exposed to captopril concentrations up to $20 \mathrm{mM}$ for the 3-4 $\mathrm{h}$ required for the migration assay.

Inhibition of migration showed some specificity for endothelial cells, for doses of captopril ranging from 0.005 to $20 \mathrm{mM}$ failed to inhibit the migration of normal human foreskin fibroblasts toward bFGF and $5 \mathrm{mM}$ captopril failed to block the migration of freshly isolated human neutrophils (29) toward the chemoattractant f-met-leu-phe (data not shown). Basic FGF stimulates both directional and random migration of endothelial cells. A checkerboard analysis showed that millimolar doses of captopril inhibited both the chemotaxis of cells migrating up a gradient of bFGF (Fig. $3 A$ ) and random chemokinesis in the absence of the gradient in a dose-dependent manner (shaded sections of Fig. $3 A$ ). In patients taking captopril, plasma concentrations do not exceed $15 \mu \mathrm{m}$ (30). Even at these low concentrations, captopril was still a potent inhibitor of endothelial cell migration, exclusively blocking directional chemotaxis (unshaded section of Fig. $3 \mathrm{~B}$ ).

Mechanism of action of captopril on endothelial cells. Angiotensin II, the product of ACE activity, can induce angiogenesis in vivo (17-20). Since cultured endothelial cells can contain the entire renin angiotensin system (31), it was possible that captopril suppressed endothelial cell migration by inhibiting ACE. But this did not seem to be the case for several reasons. First, although exogenous angiotensin II could stimulate endothelial cell migration in our assay (Fig. 4), endogenously produced compound did not play a major role for neither basal nor bFGF-induced migration was limited by antagonists to angiotensin II receptor 1 or receptor 2, although each was effective against exogenous angiotensin II (Fig. 4 and $5)$. The inhibition of migration by captopril was neither en- 


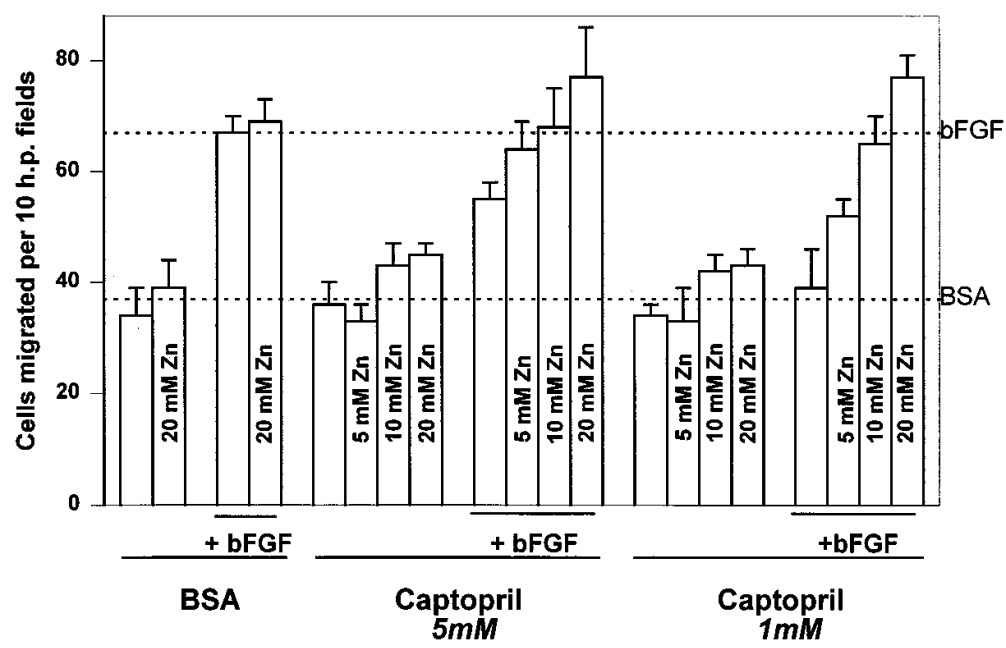

Figure 6. Ability of added zinc to relieve captopril inhibition of migration. Migration of endothelial cells toward bFGF in the presence of low and high concentrations of captopril was measured in the presence of increasing concentrations of zinc chloride $(Z n)$. hanced or inhibited by these receptor blockers. Secondly, captopril effectively inhibited migration induced by angiotensin II itself (Fig. 5). Lisinopril and enalaprilat, ACE inhibitors that resemble captopril in that they require no further metabolism to be active, but differ in that they lack captopril's free thiol

A

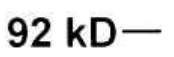

$72 \mathrm{kD}-$

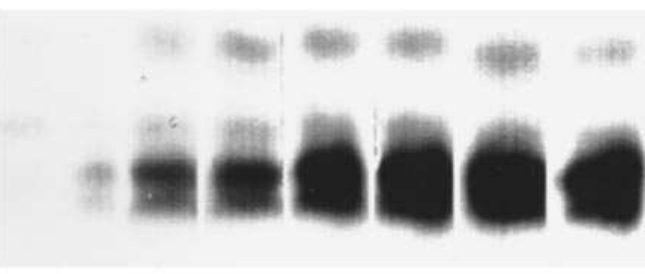

$\begin{array}{llllllll}1 & 2 & 3 & 4 & 5 & 6 & 7 & 8\end{array}$

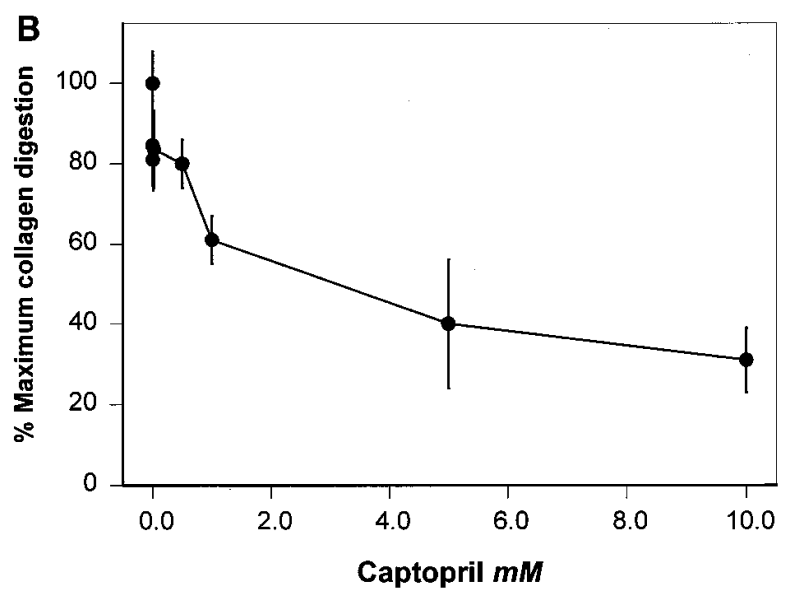

Figure 7. Effect of captopril on the activity of gelatinases secreted by capillary endothelial cells. $(A)$ Serum-free media conditioned by bovine adrenal capillary endothelial cells was run on a zymogram and identical lanes were developed for enzyme activity in the presence of the following concentrations of captopril: (1) $50 \mathrm{mM}$; (2) $25 \mathrm{mM}$; (3) $10 \mathrm{mM}$; (4) $5 \mathrm{mM}$; (5) $1 \mathrm{mM}$; (6) $0.1 \mathrm{mM}$; (7) and (8) no captopril. The positions of the 72 - and the $92-\mathrm{kD}$ gelatinases are indicated. $(B)$ The ability of purified $72-\mathrm{kD}$ gelatinase to digest collagen in a soluble assay system was measured in the presence of increasing concentrations of captopril. group, were unable to block migration induced by angiotensin II although they were effective against bFGF (Fig. 5). If captopril were blocking migration by inhibiting angiotensin II production, exogenous angiotensin II should have relieved this block and not been inhibited itself. Penicillamine, an inhibitor of neovascularization (32) structurally similar to captopril in that it contains a free thiol but which had very little ACE inhibitory activity $\left(\mathrm{ID}_{50}\right.$ for penicillamine inhibition of $\mathrm{ACE}$ was $10^{-3} \mathrm{M}$ compared to $10^{-6}-10^{-7} \mathrm{M}$ for captopril; W.F. Ward, unpublished data) behaved like captopril when tested in a similar assay at $5 \mathrm{mM}$ (data not shown).

The active thiol group present on captopril is not only essential to its ability to inhibit Zn-dependent ACE but also enables the drug to block some (33-35) but not all (36-38) other enzymes with transition metals at their active sites. To determine if the thiol was essential to the inhibition of angiogenesis by captopril, the drug was tested in the presence of increasing concentrations of $\mathrm{ZnCl}_{2}$ (Fig. 6). Although the presence of the ion alone had no effect on basal migration or on the induction of migration stimulated by bFGF, it was able to block the inhibition of migration by captopril in a dose-dependent manner, suggesting that inhibition of metal-dependent enzymes other than ACE may be responsible for the effects of captopril on endothelial cell behavior.

Captopril has previously been shown to block the activity of two matrix metalloproteinases produced by kidney cells, an action that could contribute to its renoprotective effects (33). Similar enzymes secreted by endothelial cells have been clearly shown to be essential for angiogenesis since inhibitors specific for them block the migration of activated endothelial cells in vitro and halt the formation of new vessels in vivo (3943). To determine if captopril could inhibit angiogenesis by inhibiting metalloproteinases secreted by endothelial cells, media conditioned by capillary endothelial cells were collected, run out on a nondenaturing gel containing gelatin substrate, and, after renaturing, the gel slices were assayed for enzyme activity by zymography in the presence and absence of captopril. Without drug, clear bands were seen where the $72-$ and 92-kD gelatinases had digested the substrate (Fig. $7 A$, lanes 7 and 8 ). However, in the presence of increasing concentrations of captopril, enzyme activity gradually decreased (Fig. $7 A$, lanes $6-1)$. To confirm these results, the effect of captopril on the activity of the purified $72-\mathrm{kD}$ gelatinase in a soluble assay 


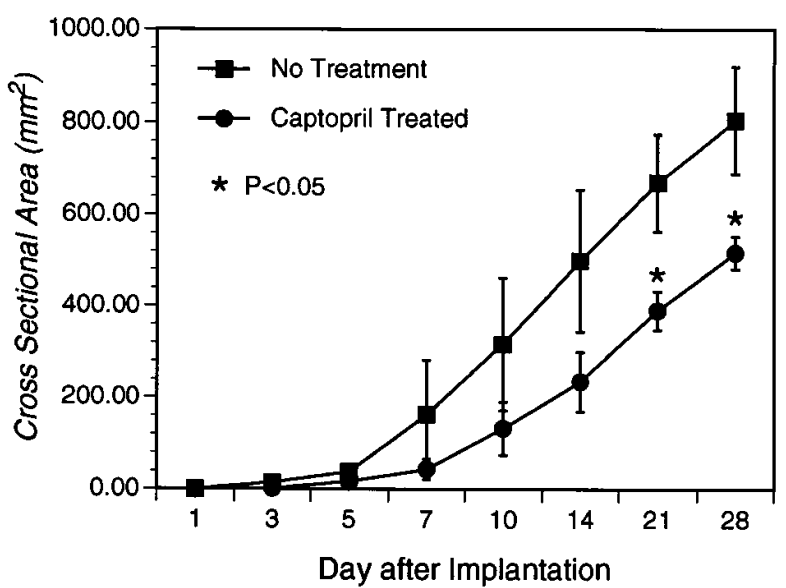

Figure 8. Reduction in the growth rate of a syngenic rat sarcoma by systemic treatment with captopril. Sarcoma cells were seeded subcutaneously and tumor area measured daily in rats fed captopril (circles) and in control-fed rats (squares). Error bars represent SEM. * Points at which significant differences $(P<0.05)$ between tumor size in control and treated animals were observed.

was examined (Fig. 7 B), and again a dose-dependent inhibition was seen.

Captopril inhibition of tumors. If captopril is an effective inhibitor of neovascularization in vivo, then systemic treat-

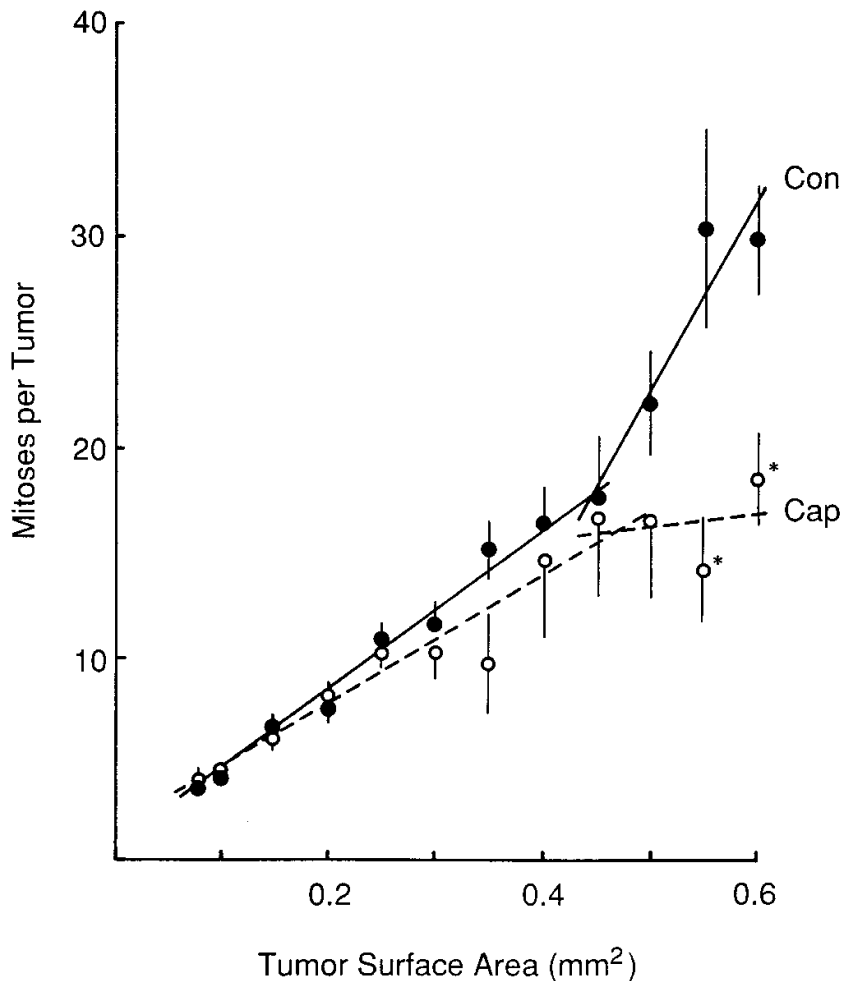

Figure 9. Reduction of mitoses in nitrosamine-induced preneoplastic foci by systemic treatment with captopril. Mitoses were counted in preneoplastic liver foci of various sizes in control-fed (solid line) and captopril-treated (broken line) animals. Mitoses per tumor diverged significantly when the lesion size exceeded $0.5 \mathrm{~mm}^{2}$. *Different from control, $P<0.05$. ment with the drug might be expected to slow tumor development, since active angiogenesis is essential for the progressive growth of solid tumors beyond a diameter of a few millimeters (44). This expectation was tested in two models. In one, a chemically induced syngeneic rat fibrosarcoma was injected subcutaneously into captopril-fed and control-fed rats. Tumor growth was significantly retarded by the drug (Fig. 8). This inhibition is unlikely to be due to a direct effect of captopril on the tumor cells themselves for they were able to clone with $>75 \%$ efficiency in captopril concentrations from $1 \mu \mathrm{M}$ to $1 \mathrm{mM}$ (data not shown). If the slowing of tumor growth is indeed due to the inhibition of angiogenesis, then experimental tumors developing in the presence of captopril would be expected to be affected by the drug only after they reach a size where oxygen and nutrient diffusion becomes limiting, a size defined experimentally as $\sim 0.4 \mathrm{~mm}^{2}$ for adenocarcinomas growing in the mouse (45). Inhibition of cell division at a similar size was seen in diethylnitrosamine-induced foci of preneoplastic cells in rat liver using the Solt-Farber model (Fig. 9). Mitoses per unit area in these foci were equivalent in treated and untreated animals only until foci of cells reached an area of between 0.4 and $0.5 \mathrm{~mm}^{2}$. In foci larger than this, numbers of mitoses accelerated in the absence of the drug, but leveled off in captopril-treated animals, as would be expected if neovascularization was limiting.

\section{Discussion}

The data presented above clearly identify captopril as an effective inhibitor of angiogenesis. In vivo it prevented the induction of neovascularization in the rat cornea. It was effective both locally and when administered orally. The ability of captopril to block both directed chemotaxis and random chemokinesis induced by angiogenic factors in cultured capillary endothelial cells suggests that the drug acts directly on capillary cells in the absence of accessory cells. Its failure to block the migration of fibroblasts toward bFGF or of neutrophils toward f-met-leu-phe indicates that it has some specificity for endothelial cells and is not acting either by interfering with the access of bFGF to its receptor or as a general inhibitor of the migratory behavior of cells. The inhibition of endothelial cell migration by captopril at first seemed contrary to earlier reports showing that captopril (46) and lisinopril (47) can stimulate the migration of cultured large vessel endothelial cells away from a confluent monolayer when a teflon fence restraining them is removed. This stimulation of random migration occurred at low micromolar concentrations of drug, reaching $154 \%$ of control values after $6 \mathrm{~d}$. It is likely that we did not see any stimulation of random migration at similar doses because our assay cells are microvascular and are exposed to drug for only 3-4 h. It is possible that captopril is a slow acting stimulator of random migration of cells cultured from large vessels but a fast acting inhibitor of the directed chemotaxis induced by tumor angiogenesis factors in capillary cells, the kind of movement that is necessary for vessel growth toward developing tumors.

The ability of captopril to inhibit endothelial cell collagenases may partially explain its antiangiogenic activity. These enzymes are induced in endothelial cells by angiogenic factors (48) and localize to the leading edge of the migrating cell. Their activity is essential for endothelial cell migration and for a positive angiogenic response in a variety of in vivo models including the cornea (39-43). We demonstrated inhibition of en- 
dothelial collagenases at millimolar concentrations of captopril. Taking advantage of avidin-linked reagents, Sorbi et al. (33) have shown that captopril can also inhibit the degradation of type IV collagen by the $72-$ or the $92-\mathrm{kD}$ gelatinases purified from kidney cells at nanomolar concentrations that are well within the levels achievable during systemic administration. Although it is clear that metalloproteinase activity is essential for new vessel formation (41-43), it is not yet possible to tell whether the inhibition of these enzymes by captopril is a major or minor contributor to the overall inhibition of angiogenesis by the drug. Its antiangiogenic effects may result from the sum of multiple activities, including, in addition to the inhibition of metalloproteinases, the modulation of the production by vascular tissue of a variety of molecules from NO to prostaglandins (49-51) that also influence angiogenesis.

As might be expected from its ability to inhibit essential metalloproteinases and depress chemotaxis at concentrations achievable in vivo, systemic treatment of animals with captopril inhibited corneal neovascularization and also had antitumor effects. When rats were chronically dosed during an in vivo carcinogenesis protocol, mitoses in the developing nests of preneoplastic liver cells leveled off just as they reached a size where tumor neovascularization becomes necessary. In another model, systemic administration of captopril slowed the overall growth of angiogenesis-dependent fibrosarcomas growing subcutaneously. In longer term studies it has been shown to significantly reduce the incidence of radiation-induced sarcomas in rats (14).

Among patients on clinical trials captopril has been shown to slightly lower the incidence of deaths due to cancer (3). Although the overall effect was not statistically significant, it could be an underestimate due to the fact that leukemias were considered together with the more angiogenesis-dependent solid tumors in calculating overall cancer deaths. Other anecdotal clinical effects are consistent with antiangiogenic effects of captopril. For example, although the drug is not toxic to embryo cultures (52), women taking it during pregnancy more frequently bear babies that are undersize for gestational age (53), a phenotype that could reflect a chronic deficit in placental or embryonic angiogenesis. These data coupled with those presented in this paper raise the possibility that for many patients taking captopril for its hypotensive action, the drug may have a hidden dividend, providing via its antiangiogenic activities a modest decrease in the incidence or severity of a variety of angiogenesis-dependent diseases including neoplasia.

\section{Acknowledgments}

This work was supported in part by grants from the National Institutes of Health, including CA52750 and CA64239 (N.P. Bouck), HL25106 (W.F. Ward), DE00313 (M.W. Lingen), HL39926 (P.J. Polverini) and CA49916 (M.D. Johnson).

\section{References}

1. Migdalof, B.H., M.J. Antonaccio, D.N. McKinstry, S.M. Singhvi, S.-J. Lan, P. Egli, and K.J. Kripalani. 1984. Captopril: pharmacology, metabolism, and disposition. Drug Metab. Rev. 15:841-869.

2. Materson, B.J., and R.A. Preston. 1994. Angiotensin-converting enzyme inhibitors in hypertension. Arch. Intern. Med. 154:513-523.

3. Pfeffer, M.A., E. Braunwald, L.A. Moye, L. Basta, E.J. Brown, T.E. Cuddy, B.R. Davis, E.M. Geltman, S. Goldman, G.C. Flaker, et al. 1992. Effect of captopril on mortality and morbidity in patients with left ventricular dysfunction after myocardial infarction. N. Engl. J. Med. 327:669-677.
4. Burris, J.F. 1995. The expanding role of angiotensin converting enzyme inhibitors in the management of hypertension. J. Clin. Pharmacol. 35:337-342.

5. Garg, R., and S. Yusuf, for the Collaborative Group on ACE Inhibitor Trials. 1995. Overview of randomized trials of angiotensin-converting enzyme inhibitors on mortality and morbidity in patients with heart failure. J. Am. Med. Assoc. 273:1450-1456.

6. Martin, M.F.R., K.E. Surrall, F. McKenna, J.S. Dixon, H.A. Bird, and V. Wright. 1984. Captopril: a new treatment for rheumatoid arthritis? Lancet i(8390): $1325-1328$

7. Jackson, W.E., D.L. Holmes, S.K. Garg, S. Harris, and H.P. Chase. 1992. Angiotensin-converting enzyme inhibitor therapy and diabetic retinopathy. Ann. Opthalmol. 24:99-103.

8. Collins, R., R. Peto, M. Flather, S. Parish, P. Sleight, M. Conway, A. Pipilis, C. Baigent, D. Barnett, J.P. Boissel, et al. 1995. ISIS-4A randomized factorial trial assessing early oral captopril, oral mononitrate, and intravenous magnesium sulphate in 58,050 patients with suspected acute myocardial infarction. Lancet. 345:669-685.

9. Young, J.B. 1994. Angiotensin-converting enzyme inhibitors in heart failure: new strategies justified by recent clinical trials. Int. J. Cardiol. 43:151-163.

10. Chobanian, A.V., C.C. Haudenschild, C. Nickerson, and R. Drago. 1990. Antiatherogenic effect of captopril in the watanabe heritable hyperlipidemic rabbit. Hypertension (Dallas). 15:327-331.

11. Ashab, I., G. Peer, M. Blum, Y. Wollman, T. Chernihovsky, A. Hassner, D. Schwartz, S. Cabili, D. Silverberg, and A. Iaina. 1995. Oral administration of L-arginine and captopril in rats prevents chronic renal failure by nitric oxide production. Kidney Int. 47:1515-1521.

12. Lewis, E.J. 1995. Captopril and diabetic nephropathy. J. Am. Med. Assoc. $273: 1831$.

13. Ward, W.F., Y.T. Kim, A. Molteni, and N.H. Solliday. 1988. Radiationinduced pulmonary endothelial dysfunction in rats: modification by an inhibitor of angiotensin converting enzyme. Int. J. Radiat. Oncol. Biol. Phys. 15:135-140.

14. Ward, W.F., A. Molteni, C. Ts'ao, and J.M. Hinz. 1990. The effect of captopril on benign and malignant reactions in irradiated rat skin. Brit. J. Radiol. 63:349-354.

15. Folkman, J., and M. Klagsbrun. 1987. Angiogenic Factors. Science (Wash. DC). 235:442-447.

16. Wang, D.-H., and R.L. Prewitt. 1990. Captopril reduces aortic and microvascular growth in hypertensive and normotensive rats. Hypertension (Dallas). 15:68-77.

17. Fernandez, L.A., J. Twickler, and A. Mead. 1985. Neovascularization produced by angiotensin II. J. Lab. Clin. Med. 105:141-145.

18. Le Noble, F.A., J.W. Hekking, H.W. Van Straaten, D.W. Slaaf, and H. A. Struyker-Boudier. 1991. Angiotensin II stimulates angiogenesis in the chorio-allantoic membrane of the chick embryo. Eur. J. Pharmacol. 195:305306.

19. Le Noble, F.A.C., N.H.J.S. Schreurs, H.W.M. Van Straaten, D.W. Slaaf, J.F.M. Smits, H. Rogg, and H.A. Struijker-Boudier. 1993. Evidence for a novel angiotensin II receptor involved in angiogenesis in chick embryo chorioallantoic membrane. Am. J. Physiol. 264:R460-R465.

20. Hernandez, I., A.W. Cowley, Jr., J.H. Lombard, and A.S. Greene. 1992. Salt intake and angiotensin II alter microvessel density in the cremaster muscle of normal rats. Am. J. Physiol. 263:H8664-H8667.

21. Tolsma, S.S., O.V. Volpert, D.J. Good, W.F. Frazier, P.J. Polverini, and N. Bouck. 1993. Peptides derived from two separate domains of the matrix protein thrombospondin-1 have anti-angiogenic activity. J. Cell Biol. 122:497-511.

22. Polverini, P.J., N.P. Bouck, and F. Rastinejad. 1991. Assay and purification of a naturally occurring inhibitor of angiogenesis. Methods Enzymol. 198: $440-450$.

23. Herron, G.S., M.J. Band, E.J. Clark, J. Gavrilovic, and Z. Werb. 1986. Secretion of metalloproteinases by stimulated capillary endothelial cells. II. Expression of collagenase and stromelysin activities is regulated by endogenous inhibitors. J. Biol. Chem. 261:2841-2848.

24. Liotta, L.A., K. Tryggvason, S. Garbisa, P.G. Robey, and S. Abe. 1981. Partial purification and characterization of a neutral protease which cleaves type IV collagen. Biochemistry. 20:100-104.

25. Solt, D., and E. Farber. 1976. New principle for the analysis of chemical carcinogenesis. Nature (Lond.). 263:701-703.

26. Polverini, P.J., and S.J. Leibovich. 1984. Induction of neovascularization in vivo and endothelial proliferation in vitro by tumor-associated macrophages. Lab. Invest. 51:635-642.

27. Zetter, B.R. 1987. Assay of capillary endothelial cell migration. Methods Enzymol. 147:135-144.

28. Bouck, N., V. Stellmach, and S. Hsu. 1996. How tumors become angiogenic. Adv. Cancer Res. 69:135-174.

29. Mansfield, P.J., L.A. Boxer, and S.J. Suchard. 1990. Thrombospondin stimulates motility of human neutrophils. J. Cell Biol. 111:3077-3086.

30. Duchin, K.L., D.N. McKinstry, A.I. Cohen, and B.H. Migdalof. 1988 Pharmacokinetics of captopril in healthy subjects and in patients with cardiovascular diseases. Clin. Pharmacokinet. 14:241-259.

31. Bell, L., D.J. Luthringer, J.A. Madri, and S.L. Warren. 1992. Autocrine angiotensin system regulation of bovine aortic endothelial cell migration and plasminogen activator involves modulation of proto-oncogene pp60 $0^{\text {c-src }}$ expres- 
sion. J. Clin. Invest. 89:315-320.

32. Matsubara, T., R. Saura, K. Hirohata, and M. Ziff. 1989. Inhibition of human endothelial cell proliferation in vitro and neovascularization in vivo by D-penicillamine. J. Clin. Invest. 83:158-167.

33. Sorbi, D., M. Fadly, R. Hicks, S. Alexander, and L. Arbeit. 1993. Captopril inhibits the $72 \mathrm{kDa}$ and $92 \mathrm{kDa}$ matrix metalloproteinases. Kidney Int. 44: 1266-1272.

34. Palatini, P., F. Dabbeni-Sala, and P. Finotti. 1989. Inhibition of dopamine $\beta$-hydroxylase by captopril. Biochem. Pharmacol. 38:1011-1013.

35. Orning, L., G. Krivi, G. Bild, J. Gierse, S. Aykent, and F.A. Fitzpatrick. 1991. Inhibition of leukotriene $\mathrm{A}_{4}$ hydrolase/aminopeptidase by captopril. $J$. Biol. Chem. 266:16507-16511.

36. Takahashi, M., Y. Matsushita, Y. Iijima, and K. Tanzawa. 1993. Purification and characterization of endothelin-converting enzyme from rat lung. $J$. Biol. Chem. 268:21394-21398.

37. Emoto, N., and M. Yanagisawa. 1995. Endothelin-converting enzyme-2 is a membrane-bound, phosphoramidon-sensitive metalloprotease with acidic pH optimum. J. Biol. Chem. 270:15262-15268.

38. Ahn, K., S. Pan, K. Beningo, and D. Hupe. 1995. A permanent human cell line (EA.HY926) preserves the characteristics of endothelin converting enzyme from primary human umbilical vein endothelial cells. Life Sci. 56:23312341.

39. Murphy, A.N., E.J. Unsworth, and W.G. Stetler-Stevenson. 1993. Tissue inhibitor of metalloproteinases-2 inhibits bFGF-induced human microvascular endothelial cell proliferation. J. Cell. Physiol. 157:351-358.

40. Fisher, C., S. Gilbertson-Beadling, E.A. Powers, G. Petzold, R. Poorman, and M.A. Mitchell. 1994. Interstitial collagenase is required for angiogenesis in vitro. Dev. Biol. 162:499-510.

41. Takigawa, M., Y. Nishida, F. Suzuki, J. Kishi, K. Yamashita, and T. Hayakawa. 1990. Induction of angiogenesis in chick yolk-sac membrane by polyamines and its inhibition by tissue inhibitors of metalloproteinases (TIMP and TIMP-2). Biochem. Biophys. Res. Commun. 171:1264-1271.

42. Moses, M.A., J. Sudhalter, and R. Langer. 1990. Identification of an inhibitor of neovascularization from cartilage. Science (Wash. DC). 248:14081410 .
43. Moses, M.A., J. Sudhalter, and R. Langer. 1992. Isolation and characterization of an inhibitor of neovascularization from scapular chondrocytes. J. Cell Biol. 119:475-482.

44. Folkman, J. 1990. What is the evidence that tumors are angiogenesis dependent? J. Natl. Cancer Inst. 82:4-6.

45. Tannock, I. 1970. Population kinetics of carcinoma cells, capillary endothelial cells and fibroblasts in a transplanted mouse mammary tumor. Cancer Res. 30:2470-2476.

46. Kohama, Y., H. Oka, N. Murayama, K. Iida, M. Itoh, X. Ying, and T. Mimura. 1992. Increase of migration of cultured endothelial cells by angiotensin-converting enzyme inhibitor derived from tuna muscle. J. Pharmacobio.Dyn. 15:223-229.

47. Bell, L., and J.A. Madri. 1990. Influence of the angiotensin system on endothelial and smooth muscle cell migration. Am. J. Pathol. 137:7-12.

48. Tsuboi, R., Y. Sato, and D.B. Rifkin. 1990. Correlation of cell migration, cell invasion, receptor number, proteinase production, and basic fibroblast growth factor levels in endothelial cells. J. Cell Biol. 110:511-517.

49. Zusman, R.M. 1987. Effects of converting-enzyme inhibitors on the renin-angiotensin-aldosterone, bradykinin and arachidonic acid-prostaglandin systems: correlation of chemical structure and biologic activity. Am. J. Kidney Dis. Suppl.X:13-23.

50. Guivernau, M., F. Armijo, and R. Rosas. 1991. Role of sulfhydryl groups in the stimulatory effect of captopril on vascular prostacyclin synthesis. Eur. J. Pharmacol. 198:1-6.

51. Warren, J.B., and R.K. Loi. 1995. Captopril increases skin microvascular blood flow secondary to bradykinin, nitric oxide, and prostaglandins. FASEB J. 9:411-418.

52. Guest, I., H.S. Buttar, S. Smith, and D.R. Varma. 1994. Evaluation of the rat embryo culture system as a predictive test for human teratogens. Can. J. Physiol. Pharmacol. 72:57-62.

53. Kreft-Jais, C., P.-F. Plouin, C. Tchobroutsky, and J. Boutroy. 1988. Angiotensin-converting enzyme inhibitors during pregnancy: a survey of 22 patients given captopril and nine given enalapril. Br. J. Obstet. and Gynaecol. 95 : 420-422. 